ISSN : 2303-1514 | E-ISSN : 2598-5949

\title{
CONTENT ANALYSIS OF CHILDREN LITERATURE (POETRY) IN THE 2013 CURRICULUM ELEMENTARY SCHOOL STUDENT BOOK IN SHAPING CHILDREN'S PERSONALITY CHARACTERISTICS: AN OVERVIEW OF STYLISTIC ANALYSIS
}

\author{
Dirneti $^{1}$, Tisrin Maulina Dewi ${ }^{2}$, Edi Kurniawan ${ }^{3}$ \\ ${ }^{1,2,3}$ Universitas Karimun, Kepulauan Riau, Indonesia \\ 1dirnetiz@gmail.com, 2tisrinmaulinadewi@gmail.com,3edikurniawank46@gmail.com
}

\section{ANALISIS MUATAN SASTRA (PUISI) ANAK DALAM BUKU TEMATIK SISWA SD KURIKULUM 2013 SEBAGAI PEMBENTUK KARAKTERISTIK KEPRIBADIAN ANAK: TINJAUAN ANALISIS STILISTIK}

\begin{tabular}{|c|c|}
\hline ARTICLE HISTORY & ABSTRACT \\
\hline $\begin{array}{l}\text { Submitted: } \\
\text { 14 Juni } 2021 \\
\text { 14 } 4^{\text {th }} \text { June } 2021\end{array}$ & $\begin{array}{l}\text { Abstract: Literary work is the result of an author's imagination through the medium of } \\
\text { language. One form of literary works is poetry. As a literary work, poetry is bound to lines and } \\
\text { stanzas. In this study, we discussed the problem of how the content of children's literature } \\
\text { (poetry) contained in the } 2013 \text { curriculum thematic book of elementary school in shaping the } \\
\text { students' personality characteristics viewed from stylistic analysis. The purpose of the study } \\
\text { was to determine the stylistics of children's poetry contained in the } 2013 \text { curriculum thematic } \\
\text { books of elementary school. The type of this research was qualitative research using } \\
\text { descriptive method. This research was in the form of a documentation study, which analyzed } \\
\text { the forms of poetry contained in the thematic books of elementary school. Thus, the object of } \\
\text { this research was these forms of poetry. Based on the results of data analysis, it was found that } \\
\text { the children's poetry contained in elementary school students' books used several sound } \\
\text { elements, such as rhyme, alliteration, assonance, anaphora, epanalepsis, mesodiplosis, and } \\
\text { onomatopoeia. Meanwhile, the use of diction found in the book was in the form of Arabic } \\
\text { diction. Then, the use of images was in the form of images of sight, hearing, smell, and taste } \\
\text { while the figures of speech used in this book were personification, hyperbole, metaphor, and } \\
\text { simile. Then, it was also found several language deviation, such as morphological, syntactic, } \\
\text { and graphological deviations. The forms of children's poetry contained in the thematic books of } \\
\text { elementary school weredesigned in accordance with the characteristics of children's poetry. } \\
\text { This was seen from the way the elements of sound, diction, figure of speech, images, and } \\
\text { language deviations are used. }\end{array}$ \\
\hline
\end{tabular}

$25^{\text {th }}$ July 2021

Keywords: literature, poetry, stylistic

\begin{abstract}
Abstrak: Karya sastra merupakan hasil imajinasi seorang pengarang dengan menggunakan medium bahasa. Salah satu bentuk karya sastra adalah puisi. Puisi adalah karya sastra yang terikat pada larik dan bait. Di dalam penelitian ini akan membahas permasalahan bagaimanakah muatan sastra (puisi) anak yang terdapat dalam buku tematik siswa sekolah dasar kurikulum 2013 sebagai pembentuk karakteristik kepribadian anak ditinjau dari sudut analisis stilistika? Tujuan penelitian adalah untuk mengetahui stilistik puisi anak yang terdapat dalam buku tematik siswa sekolah dasar kurikulum 2013. Jenis penelitian ini adalah penelitian kualitatif dengan menggunakan metode deskriptif. Penelitian ini berbentuk studi dokumentasi yaitu menganalisis bentuk-bentuk puisi yang terdapat di dalam buku tematis siswa SD. Bentukbentuk puisi tersebut merupakan objek dalampenelitian ini. Berdasarkan hasil analisis data ditemukan bahwa dalam bentuk-bentuk puisi anak pada buku siswa sekolah dasar menggunakan beberapa unsur bunyi yaitu berupa rima, aliterasi, asonansi, anafora, epanalepsis, mesodiplosis, dan onomatope. Sementara itu, penggunaan diksi yang ditemukan adalah berbentuk diksi dari bahasa asing yaitu bahasa Arab. Adapun penggunaan imaji atau citraan adalah berbentuk citraan penglihatan, pendengaran, penciuman, dan pengecapan. Sedangkan pemanfaatan unsur majas adalah berupa majas personifikasi, hiperbola, metafora, dan simile. Kemudian dalam penyimpangan bahasa ditemukan adanya penyimpangan morfologis, sintaksis, dan grafologis. Bentuk-bentuk puisi anak yang terdapat dalam buku tematik siswa sekolah dasar ini sudah sesuai dengan karakteristik puisi anak. Hal ini terlihat
\end{abstract}




\section{CITATION}

Dirneti, D., Dewi, T. M., \& Kurniawan, E. (2021). Content Analysis of Children Literature (Poetry) in the 2013 Curriculum Elementary School Student Book In Shaping Children's Personality Characteristics: An Overview Of Stylistic Analysis. Primary: Jurnal Pendidikan Guru Sekolah Dasar, 10 (3), 803-817. DOI: http://dx.doi.org/10.33578/jpfkip.v10i4.8462 .

\section{PENDAHULUAN}

Karya sastra merupakan hasil kerja kreatif seorang penyair dengan menggunakan medium bahasa. Oleh karena itu, bahasa sangat esensial dalam sebuah karya sastra. Sebagaimana yang dikatakan Wellek dan Warren (1993: 14-15) bahwa bahasa adalah bahan baku kesusastraan. Melalui bahasa para sastrawan dapat mengolah dan mengajukan apa yang dipikirkan dan dirasakannya. Bahasa sastra adalah bahasa yang khas. Seperti yang dikatakan Teeuw (dalam Sudjiman, 1993: 2) bahwa sastra adalah penggunaan bahasa yang khas, yang hanya dapat dipahami dengan pengertian, konsepsi bahasa yang tepat. Dengan demikian dapat dikatakan bahwa makna sebuah karya sastra bisa dipahami apabila mengerti dengan konsepsi bahasa.

Keindahan bahasa sastra akan mudah terlihat bila ditinjau melalui pendekatan stilisitika. Stilistika merupakan kajian keindahan bahasa sastra. Selain itu, stilistika pun dapat menunjukkan bagaimana unsurunsur suatu teks berkombinasi membentuk suatu pesan. Manfaat pendekatan stilistika cukup besar dalam menjabarkan ciri-ciri khusus suatu karya sastra. Melalui pendekatan stilistika bisa dilihat ciri khas karya sastra atau sekelompok karya sastra. Seperti yang dikatakan Wellek dan Warren (1993: 229) bahwa analisis stilistika akan membawa keuntungan besar bagi studi sastra, jika dapat menentukan suatu prinsip yang mendasari kesatuan karya sastra, dan jika dapat menemukan suatu tujuan estetika umum yang menonjol dalam sebuah karya sastra dari keseluruhan unsurnya.
Salah satu bentuk penerapan analisis stilistika dalam karya sastra adalah pada bentuk puisi. Sehubungan dengan hal ini, penulis mencoba meneliti kumpulan puisi yang terdapat dalam buku tematik siswa sekolah dasar kurikulum 2013 dengan menggunakan tinjauan stilistika sebagai pendekatannya Pembelajaran puisi merupakan salah satu materi pelajaran yang terdapat dalam Kurikulum 2013 (K13) untuk siswa Sekolah Dasar (SD). Puisi adalah salah satu genre sastra selain prosa dan drama. Sebagai bagian dari pembelajaran sastra, pembelajaran puisi memiliki manfaat yang sangat penting bagi siswa terutama dalam rangka membentuk kepribadian (personal value) dan menanamkan nilai-nilai pendidikan (educational value).

Puisi sebagai bagian dari karya sastra merupakan bentuk imajinasi yang dituangkan melalui medium bahasa. Pengarang akan mengolah potensi bahasa dalam rangka menghasilkan karya tersebut. Untuk karya sastra yang ditujukan bagi anak-anak, dalam hal ini siswa SD, maka ada karakteristik tertentu yang harus diperhatikan terutama dalam hal penggunaan bahasa dan tema yang diangkat.

Karakteristik sastra anak menurut Supriyadi (2006: 12) terbagi atas dua bagian yaitu ditinjau dari segi kebahasaan dan dari segi kesusastraan. Dari segi kebahasaan akan terlihat melalui penggunaan struktur kalimat, pilihan kata, serta gaya bahasa. Adapun bila ditinjau dari segi kesusastraan maka terlihat melalui tema, pemakaian majas, serta persajakan dan irama untuk genre puisi. Sedangkan Sarumpaet (dalam Supriyadi, 
2006: 21) menyatakan bahwa sastra anak memiliki tiga ciri pembeda yaitu berupa unsur pantangan, penyajian dengan gaya secara langsung, dan fungsi terapan.

Di dalam buku siswa Kurikulum 2013, bentuk-bentuk puisi ditemukan mulai dari kelas I SD sampai kelas VI SD. Bentukbentuk puisi tersebut tersebar dalam tema, subtema, dan pembelajaran. Berdasarkan pengamatan penulis, bentuk puisi yang paling banyak adalah terdapat dalam Buku Tematik Siswa kelas II. Oleh karena itu, dalam penelitian ini akan digunakan Buku Tematik Siswa kelas II yaitu yang berjudul: Pengalamanku, Buku Tematik Terpadu Kurikulum 2013, Tema 5. Di dalam buku tematik siswa ini terdapat 17 bentuk puisi. Kesemua bentuk puisi tersebut akan dijadikan objek dalam penelitian ini. Bentuk-bentuk puisi tersebut berjudul: Pelangi-pelangi, Lihat Kebunku, Taman Bungaku, Burung Kutilang, Burung Berkicau, Tik tik tik Bunyi Hujan, Hujan, Ketupat Lebaran, Layang-layang, Kunang-kunang, Cemara, Kupu-kupu, Paman Datang, Nyiur Hijau, Pemandangan, Air Terjun, dan Desaku.

\section{KAJIAN TEORI}

Sastra adalah pengalaman kemanusiaan yang dikembangkan melalui imajinasi dan bersifat pribadi. Dikatakan bersifat pribadi karena subjektivitas pengarang pasti mewarnai karya tersebut. Sebagaimana yang dikatakan Gani (1988: 3) bahwa substansi sastra tidak lain adalah pengalaman kemanusiaan, hubungan kompleks yang melibatkan seseorang, emosi yang membuatnya menderita atau bahagia, pengalaman yang dihadapinya, nilai serta kebermaknaannya yang diharapkan.

Sastra merupakan sebuah karya yang dirakit oleh seorang sastrawan atau penyair dengan segala kemampuannya. Melalui karyanya itu seorang sastrawan dapat menampilkan ciri pribadinya. Seperti yang dikatakan Sumarjo (1986: 3) bahwa sastra adalah ungkapan pribadi manusia berupa pengalaman, pemikiran, perasaan, ide, dan keyakinan dalam suatu bentuk gambaran yang konkret yang membangkitkan pesona dengan alat bahasa. Selanjutnya Sudjiman (1993: 7) menyatakan bahwa karya sastra merupakan wacana yang khas yang menggunakan bahasa dengan berbagai kemungkinan yang ada untuk pengekspresian. Dari uraian di atas dapat dikatakan bahwa bahasa sangat penting dalam usaha pengekspresian karya sastra.

Di dalam penelitian ini, penulis akan mengkaji tentang sastra anak. Hakekat sastra anak menurut Supriyadi (2006: 4) adalah karya sastra imajinatif yang ditulis oleh anakanak maupun orang dewasa yang ditujukan bagi anak-anak dengan menggunakan bahasa yang mengandung pengalaman, pikiran, dan perasaan anak-anak. Hal ini sejalan dengan pendapat Stewig (dalam Supriyadi: 3) yang menyebutkan bahwa sastra anak adalah sastra yang ditulis memang ditujukan bagi anakanak. Dengan demikian dapat dikatakan bahwa sastra anak adalah karya sastra yang ditujukan bagi anak-anak dengan menggunakan bahasa.

Sastra anak mengandung berbagai manfaat. Hal ini tidak dapat diragukan. Huck et al., dalam (Supriyadi, 2006) menyatakan bahwa nilai yang terdapat dalam karya sastra dikelompokkan menjadi dua bagian yaitu (1) dilihat dari segi kepribaadian anak (personal value) dan dilihat dari nilai pendidikan anak (educational vaule). Sedangkan Sarumpaet dalam (Santosa, 2003) menyatakan bahwa manfaat sastra anak adalah hal yang dapat diterapkan dalam kehidupannya.dengan demikian maka dapat dikatakan bahwa sastra anak bermanfaat dari segi kepribadian dan pendidikan yang dapat dimanfaatkan dalam kehidupan anak.

Berdasarkan pendapat di atas maka bisa disimpulkan bahwa sastra anak memiliki karakteristik tertentu dari segi kebahasaan, kesusastraan, maupun dari fungsi manfaat.

Sastra anak memiliki karakteristik tersendiri. Supriyadi (2003: 12) menyebutkan bahwa karakteristik sastra anak dapat dilihat 
dari beberapa segi, di antaranya dari segi kebahasaan dan kesusastraan. Dari segi kebahasaan, dilihat dari penggunaan kalimat, sastra anak banyak mengandung kalimat tunggal yang sederhana. Jika dilihat dari pemakaian diksi atau pilihan kata, banyak menggunakan kata yang sudah dikenal atau kata konkret. Sedangkan jika dilihat dari penggunaan gaya bahasa memang tidak terlalu banyak digunakan. Tetapi ada majas yang sering digunakan yaitu majas personifikasi.

Di sisi lain, Nurgiyantoro (2019: 134) menyebutkan bahwa sastra anak terdiri dari berbagai genre yang dapat berbentuk lisan maupun tulisan. Sastra anak dapat berupa lagu ninabobo, puisi lagu, tembang dolanan, dan lain sebagainya. Bila dilihat dari segi puisi, karakteristiknya lebih dominan dalam hal pendayaan rima dan irama. Anakanak lebih mendapatkan rasa senang dan kepuasan dari adanya permainan-permainan bunyi dalam puisi daripada intensitas akan kandungan makna. Kepuasan dan kesenangan anak pada puisi lebih banyak didapatkan karena adanya bunyi-bunyi pada puisi dibandingkan intensitas kandungan maknanya.

Sementara itu Sarumpaet (dalam Supriyadi, 2006: 21) menyebutkan karakteristik sastra anak ada tiga yaitu: (1) unsur pantangan, (2) penyajian dengan gaya secara langsung, dan (3) fungsi terapan. Unsur pantangan berkaitan dengan tema dan amanat yang diangkat tidak mengandung unsur yang menimbulkan kebencian, kekerasan, prasangka buruk, kekejaman, seks, cinta yang erotis, dendam, kecurangan, dan masalah kematian. Adapun penyajian secara langsung berkaitan dengan deskripsi cerita secara singkat yang langsung pada sasaran di mana tokohnya mempunyai satu sifat utama hitam atau putih. Sedangkan fungsi terapan adalah unsur manfaat yang dapat diambil dari sastra tersebut yaitu berupa pengetahuan umum, keterampilan khusus, maupun untuk pertumbuhan anak.
Berdasarkan pendapat di atas maka bisa disimpulkan bahwa sastra anak memiliki karakteristik tertentu dari segi kebahasaan, kesusastraan, maupun dari fungsi manfaat.

Salah satu genre sastra anak adalah puisi. Puisi berasal dari bahasa Yunani yaitu kata 'poima' yang berarti pembuatan. Adapun dari bahasa Inggris berasal dari kata 'poetry' yang artinya membuat atau pembuatan. Sedangkan Supriyadi (2006: 57) menyatakan bahwa puisi adalah karya sastra yang menggunakan kata-kata, rima, irama sebagai media dalam berekspresi dan berimajinasi. Sementara itu, Waluyo (1987: 3) menjelaskan bahwa puisi adalah bentuk karya sastra yang paling tua. Altenbern (dalam Pradopo, 1995: 6) mengungkapkan bahwa puisi adalah pendramaan pengalaman yang bersifat penafsiran dalam bahasa yang berirama. Sementara itu, Worswoth (dalam Semi, 1988: 93) merumuskan pengertian puisi: Poetry is the best words in the best order. Artinya puisi adalah kata-kata yang terbaik dalam susunan yang terbaik. Selanjutnya, Watts-Dunton dan Lascelles Abercrombie (dalam Tarigan, 1993: 7) menyatakan bahwa puisi adalah ekspresi yang konkret dan bersifat artistik dari pikiran manusia dalam bahasa emosional dan berirama.

Dari beberapa rumusan pengertian puisi di atas dapat ditarik kesimpulan bahwa unsur pokok yang menjadi ciri khas puisi yaitu: (1) puisi itu terbentuk karena adanya pendramaan pengalaman dalam penafsiran dan menggunakan bahasa yang indah, (2) puisi adalah ungkapan pengalaman imajinatif yang bernilai dan punyai arti yang disampaikan dalam bahasa yang tepat, dan (3) puisi memiliki rangkaian bentuk atau struktur tertentu.

Sebuah hasil karya seni ciri khasnya adalah menyampaikan informasi tertentu dalam bentuk yang indah. Jadi kalau kita membaca dan sekaligus ingin menganalisis sebuah hasil karya seni seperti puisi, maka ada dua hal yang diketahui atau diperhatikan yaitu 
informasi dan keindahan. Cara untuk membentuk keindahan dalam puisi ini disebut dengan stilistika. Istilah stilistika didefinisikan Endraswara (2011: 71-72) dengan beberapa pengertian, seperti stilistika merupakan ilmu pemanfaatan bahasa dalam karya sastra. Stilistika adalah ilmu yang mempelajari gaya bahasa suatu karya sastra. Dan, stilistika adalah penggunaan gaya bahasa secara khusus dalam karya sastra.

Pendekatan analisis stilistika sangat bermanfaat dalam menemukan aspek-aspek estetis pembentuk kepuitisan karya sastra. Bagi penyair yang dapat memanfaatkan penggunaan stilistika maka akan membuat karyanya semakin mengandung seni yang berbobot. Sebagaimana dikatakan Pradopo (dalam Endraswara, 2011: 72) bahwa nilai seni sastra sangatlah ditentukan oleh pemakaian gaya bahasanya. Keahlian seorang penyair dalam memainkan stilistika dapat menentukan kepiawaian ranah estetisnya. Sejalan dengan pendapat tersebut, Ratna (2017: 3) juga menyatakan bahwa stilistika adalah ilmu tentang gaya. Gaya seorang penyair dalam menghasilkan dan mengekspresikan sebuah karya dalam bidang sastra.

Dari beberapa pendapat tersebut maka dapat dikatakan bahwa stilisitika merupakan pengkajian tentang bagaimana seorang penyair dalam membuat karya sastra dilihat dari pengolahan dan pemanfaatan potensi bahasa sehingga bisa menunjang keindahan karyanya. Salah satu bentuk karya sastra adalah puisi. Puisi memiliki beberapa unsur penunjang keindahan. Unsur keindahan itu dapat berupa bunyi, diksi, imaji (citraan), majas (bahasa kiasan), dan penyimpangan bahasa.

Bunyi merupakan unsur penting dalam sebuah puisi. Kepuitisan sebuah puisi terkadang sangat terlihat dalam bunyi yang dikandungnya. Sebagaimana yang dikatakan Atmazaki (1993: 78) bahwa bunyi yang terdapat dalam dalam sajak merupakan salah satu keindahan yang cukup berarti.
Keberadaan bunyi dalam sebuah puisi dapat menciptakan kesan dan efek tersendiri. Bunyi yang berperan dalam sebuah puisi adalah bunyi yang teratur atau bunyi yang terpola. Bunyi yang teratur atau terpola ini bisa berupa rima, asonansi dan aliterasi, anafora, epizeuksis, epanalepsis, mesodiplosis, epistrofa, simploke, onomatope, dan anadiplosis.

Rima merupakan persamaan bunyi (Budianta, 2008: 41). Pendapat ini senada juga dengan pendapat Kosasih (2012: 104) yang mengatakan bahwa rima adalah pengulangan bunyi. Bunyi yang berulang ini biasanya terdapat di akhir baris sajak, tetapi ada juga yang terletak di awal atau di tengah baris. Rima biasanya ditandai dengan huruf abjad, seperti ab-ab; cde-cde; b-b; dan lainlain. Dari pendapat tersebut dapat disimpulkan bahwa rima merupakan persamaan bunyi yang bisa terletak di awal, di tengah, maupun di akhir baris sajak.

Ada beberapa istilah pengulangan bunyi, seperti asonansi adalah gaya bahasa yang berwujud perulangan bunyi vokal yang sama dalam satu baris sedangkan untuk konsonan disebut aliterasi. Anafora untuk menyatakan perulangan kata pertama pada tiap baris atau kalimat berikutnya. Sedangkan repetisi yang bersifat langsung di mana sebuah kata yang dianggap penting diulang berkali-kali secara berturut-turut diberi isitilah epizeuksis. Adapun perulangan kata atau frasa pada akhir baris atau kalimat berurutan dinamai dengan istilah epistrofa. Sementara itu ada istilah simploke yaitu repetisi awal dan akhir baris, beberapa baris atau kalimat berturut-turut. Mesodiplosis merupakan istilah untuk repetisi di tengah baris-baris atau kalimat berurutan. Epanalepsis adalah istilah untuk pengulangan yang berwujud kata terakhir dan baris, klausa atau kalimat, mengulang kata pertama. Anadiplosis istilah untuk kata atau frasa terakhir dari suatu klausa atau kalimat menjadi kata atau frasa pertama dari klausa atau kalimat berikutnya. (Keraf, 2007: 130). 
Diksi atau kata dalam sebuah puisi sangat besar peranannya. Menurut Atmazaki (1993: 31) kata adalah alat sajak yang utama. Segala unsur kepuitisan sajak bertumpu pada kata dengan segala kemungkinan atau potensi yang ada padanya. Penggunaan diksi yang dilakukan oleh seorang sastrawan tidak lain adalah untuk mewujudkan segala ide yang ada padanya. Melalui diksi yang bisa jadi berasal dari bahasa daerah, asing, maupun vulgar dapat dimanfaatkan sastrawan untuk menghidupkan karyanya.

Unsur kepuitisan yang cukup besar pula peranannya dalam sebuah puisi adalah pemakaian majas. Majas atau figurative language dapat menimbulkan kesegaran, menarik perhatian, hidup, dan terutama menimbulkan kejelasan gambaran angan (Pradopo, 1995: 61-62). Dengan adanya majas, maka sebuah karya sastra seakan memiliki nafas. Pembaca seolah berhadapan dengan benda nyata yang dapat berkomunikasi, sehingga mempunyai kesan yang lebih mendalam dan bermakna.

Pemakaian majas yang disebut juga dengan bahasa kiasan ini ada bermacammacam. Ada yang disebut dengan majas perbandingan, metafora, perumpamaan, personifikasi, hiperbola, dan retoris.Majas perbandingan atau simile ialah bahasa kiasan yang menyamakan suatu hal dengan hal lainnya dengan mempergunakan kata-kata pembanding seperti: bagai, sebagai, bak, seperti, semisal, seumpama, laksana, sepantun, penaka, se, dan kata-kata pembanding lainnya. Adapun metafora merupakan bahasa kiasan yang juga hampir sama dengan majas perbandingan, tetapi tidak menggunakan kata-kata pembanding.

$$
\text { Majas perumpamaan adalah }
$$

perbandingan yang dilanjutkan atau diperpanjang, yaitu dibentuk dengan cara melanjutkan sifat-sifat pembanding lebih lanjut dalam kalimat-kalimat atau frase-frase yang berturut-turut. Sedangkan majas allegori merupakan cerita kiasan ataupun lukisan kiasan. Cerita kiasan atau lukisan kiasan ini mengiaskan hal lain atau kejadian lain.

Penggunaan majas lainnya yang cukup banyak terdapat dalam puisi adalah majas personifikasi. Majas personifikasi adalah mempersamakan benda dengan manusia. Benda-benda dapat berbuat seperti manusia (Altenbernd dalam Pradopo: 77). Di dalam puisi, sastrawan sering juga menggunakan imaji (citraan) untuk menambah kepuitisan sebuah puisi. Citraan adalah gambaran-gambaran angan dalam pikiran dan bahasa yang menggambarkannya (Altenbernd dalam Pradopo: 80), sedangkan setiap gambar pikiran disebut citra atau imaji (image). Dijelaskan pula bahwa gambaran angan ini ada bermacam-macam, seperti dihasilkan oleh indera penglihatan, pendengaran, penciuman, pengecapan, dan perabaan (Pradopo: 81)

Seorang penyair mempunyai kewenangan untuk mempergunakan licentia poetica dalam berkarya. Lisensia puitika adalah kebebasan penyair dalam mengolah potensi bahasa (Ratna, 2017: 211). Sering pula penyair melakukan pelanggaran terhadap kaidah bahasa yang baku. Namun semuanya dilakukan untuk menyampaikan pesan yang terbaik juga keindahan terhadap karya ciptanya. Penyimpangan bahasa yang sering terjadi adalah berbentuk penghilangan imbuhan, pemutusan frasa, penggabungn kata, penyimpangn struktur sintaksis, pengubahan jenis kata, pemendekan kata, dan penghapusan tanda baca.

Unsur keindahan yang terdapat dalam puisi mudah terlihat bila ditinjau melalui pendekatan stilistika. Selain itu, stilistika dapat menunjukkan bagaimana unsur-unsur suatu teks berkombinasi membentuk sebuah pesan. Dengan kata lain, bagaimana karya sastra berlaku sebagai suatu sarana komunikasi (Sudjiman: 7).

Berkaitan dengan rumusan stilistik ini, Syamsir (1991: 125) menyatakan bahwa stilistik adalah ilmu yang menyelidiki bahasa yang dipergunakan dalam karya sastra: 
interdisipliner antara linguistik dan kesusastraan, penerapan linguistik pada penelitian gaya bahasa. Sedangkan bahasa stilistik adalah cara tersendiri yang dilakukan penulis dalam menyatakan atau menggambarkan suatu hal dengan mengemukakan bentuk-bentuk asosiasi, perumpamaan, perbandingan atau kiasan yang tepat (Natawidjaya: 1). Sementara itu, Semi (1990: 14) mengungkapkan bahwa stilistika adalah kajian keindahan bahasa sastra, khususnya untuk menjelaskan atau membuktikan sejauh mana keberhasilan sastrawan mengolah bahasa sebagai bagian kreatif imajinatif yang bersifat figuratif, simbolik, serta memiliki estetik.

Berdasarkan beberapa pengertian stilistik di atas maka dapat disimpulkan bahwa: (1) stilistika berkaitan dengan pemanfaatan bahasa dalam karya sastra, (2) stilistika mengkaji gaya bahasa, mengolah dan membentuk keindahan dan makna karya sastra, dan (3) gaya sastrawan atau penyair dapat dilihat dari karya sastra yang dihasilkannya.

Di dalam penelitian ini, penulis menggunakan buku tematik karangan Taufina yang berjudul Pengalamanku, Tematik Terpadu Kurikulum 2013, Tema 5, Untuk Siswa SD/MI Kelas II, edisi Revisi 2017, terbitan Kementerian Pendidikan dan Kebudayaan. Buku ini penulis jadikan objek penelitian karena memuat bentuk-bentuk puisi paling banyak dibandingkan buku tematik yang lain.

\section{METODE PENELITIAN}

Penelitian ini menggunakan metode deskriptif, yaitu suatu metode dalam meneliti status sekelompok manusia, suatu objek, suatu set kondisi, suatu kelas peristiwa pada masa sekarang. Sedangkan pendekatan yang digunakan adalah pendekatan kualitatif. Kirk dan Miller (dalam Moleong, 1990: 3) mengatakan bahwa penelitian kualitatif adalah tradisi tertentu dalam ilmu pengetahuan sosial yang secara fundamental bergantung pada pengamatan pada manusia dalam kawasannya sendiri dan berhubungan dengan orang-orang tersebut dalam bahasanya dan peristilahannya. Sementara itu, sekaitan dengan penelitian sastra Ratna (2015: 48) mengatakan bahwa dalam metode analisis karya sastra yang dianalisis adalah pesan-pesan yang sesuai dengan hakekat sastra.

Penelitian ini berbentuk studi dokumentasi yaitu menganalisis bentukbentuk puisi yang terdapat dalam buku tematik siswa SD. Teknik pengambilan sampel adalah berbentuk purposive sample. Sampel yang digunakan adalah bentuk-bentuk puisi yang terdapat dalam buku tematik siswa kelas II SD. Buku ini penulis gunakan karena pada buku tersebut telah cukup mewakili bahan kajian yang akan penulis analisis.

Instrumen yang digunakan dalam penelitian ini adalah berupa tabel analisis, yaitu tabel analisis unsur bunyi, tabel analisis diksi, tabel analisi imaji/citraan, tabel analisis majas, dan tabel analisis penyimpangan bahasa. Di dalam mengolah dan menganalisis data penulis menggunakan Tabel 1 .

Tabel 1. Analisis Unsur Bunyi

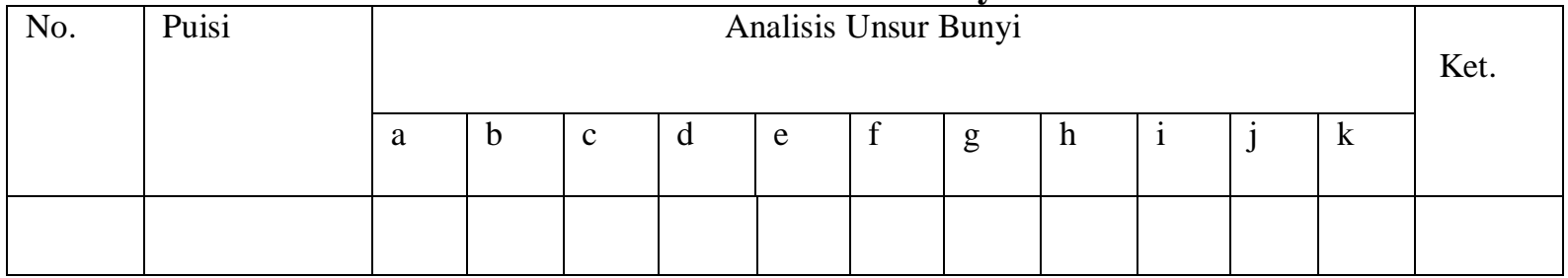

Sumber: Olahan Peneliti 2021 


\begin{tabular}{|c|c|c|}
\hline Keterangan: & simbol analisis: & f. Epanalepsis \\
\hline a. Rima & (1) & g. Mesodiplosis \\
\hline b. Aliterasi & (2) & h. Epistrofa \\
\hline c. Asonansi & (3) & i. Simploke \\
\hline d. Anafora & (4) & j. Onomatope \\
\hline e. Epizeuksis & (5) & k. Anadiplosis \\
\hline
\end{tabular}

Tabel 2. Analisis Diksi

\begin{tabular}{|l|l|l|l|l|}
\hline No & Puisi & Kosakata Daerah & Kosakata Asing & Kosakata Vulgar \\
\hline & & & & \\
\hline
\end{tabular}

Sumber: Olahan Peneliti 2021

Tanda dalam Puisi yang Dianalisis untuk: $\quad$ Kosakata Asing (warna hijau Kosakata Daerah (warna merah) Kosakata Vulgar/Kasar (warna kuning)

Tabel 3. Analisis Imaji (Citraan)

\begin{tabular}{|l|l|l|l|l|l|l|l|}
\hline No. & Puisi & a & b & c & d & e & Ket. \\
\hline & & & & & & & \\
\hline
\end{tabular}

Sumber: Olahan Peneliti 2021

c. Citraan Penciuman : kurung kurawal $\{\mathrm{c}\}$

Keterangan:

simbol analisis:

a. Citraan Penglihatan : kurung biasa (a)

b. Citraan Pendengaran : kurung siku [b ] d. Citraan Perabaan : garis miring / d /

e. Citraan Pengecapan : tanda lebih besar lebih kecil <e>

Tabel 4. Analisis Majas (Bahasa Kiasan)

\begin{tabular}{|l|c|c|c|}
\hline No. & Puisi & Majas yang Digunakan & Ket. \\
\hline & & & \\
\hline
\end{tabular}

Sumber: Olahan Peneliti 2021

Tabel 5. Analisis Penyimpangan Bahasa (morfologis, sintaksis, dan grafologis)

\begin{tabular}{|l|l|l|l|}
\hline No. & Puisi & Bentuk Penyimpangan Bahasa & Seharusnya/baku \\
\hline & & & \\
\hline
\end{tabular}

Sumber: Olahan Peneliti 2021

\section{HASIL DAN PEMBAHASAN}

Melalui penelitian ini ditemukan beberapa unsur bunyi yang terdapat dalam bentuk puisi pada buku tematik siswa Sekolah Dasar. Unsur bunyi tersebut berbentuk rima, aliterasi, asonansi, epizeuksis, anafora, epanalepsis, mesodiplosis, dan onomatope.

Unsur bunyi berbentuk rima, aliterasi, asonansi, anafora, epizeuksis, dan mesodiplosis dapat terlihat pada contoh puisi "Hujan" berikut ini:

\section{Hujan}

(simbol analisis)

1 Hujan, hujan di mana-mana,

(2), (5)

2 di jalan di halaman semua basah,

(2), (3), (7)

3 hujan, hujan tak henti henti,

(1), (2), (5)

4 hujan hujan lebat sekali.

(1), (2), (4), (5) 
5 Hujan, Hujan bukan kepalang

(1), (2), (5)

6 di sana dan di sini air tergenang,

(1), (2), (7)

7 hujan hujan belum berhenti,

(1), (2), (5)

8 hujan hujan sepanjang hari

(1), (2), (4), (5)

(subtema 1, pengalamanku di rumah, pembelajran ke-6, hal: 59)

Berdasarkan simbol analisis, di dalam bentuk puisi tersebut ditemukan ada beberapa unsur bunyi. Unsur bunyi tersebut adalah berbentuk rima yang terletak pada kata henti, sekali, berhenti, dan hari yaitu persamaan bunyi /i/. Kemudian kata kepalang dan tergenang yaitu persamaan bunyi $/ \mathrm{y} /$. Selain itu ada juga unsur bunyi berbentuk aliterasi yang terdapat dalam semua baris puisi. Seperti pada baris 1 terdapat kata hujan dan hujan, pengulangan konsonan $/ \mathrm{h} /$ dan $/ \mathrm{n} /$. Pada baris ke-2 terdapat kata di, jalan, di, dan halaman, pengulangan konsonan $/ \mathrm{d} /$, dan $/ \mathrm{n} /$. Pada baris ke-3 terdapat kata hujan, hujan, henti dan henti, pengulangan konsonan $/ \mathrm{h} / \mathrm{dan} / \mathrm{n} /$. Pada baris ke-4 terdapat kata hujan dan hujan, pengulangan konsonan $/ \mathrm{h} / \mathrm{dan} / \mathrm{n} /$. Pada baris ke-5 terdapat kata hujan, hujan, dan bukan, pengulanganckonsonan $/ \mathrm{h} / \mathrm{dan} / \mathrm{n} /$. Pada baris ke-6 terdapat kata di, sana, dan, di, dan sini, pengulangan konsonan /d/, /s/, dan /n/. Pada baris ke-7 terdapat kata hujan, hujan, belum, dan berhenti, pengulangan konsonan $/ \mathrm{h} /, / \mathrm{n} /$, dan /b/. Pada baris ke-8 terdapat kata hujan dan hujan, pengulangan konsonan $/ \mathrm{h} / \mathrm{dan} / \mathrm{n} /$.

Selain aliterasi ada juga bentuk asonansi yaitu terdapat pada baris ke-2 kata $d i$ dan $d i$, pengulangan vocal /i/. Asonansi adalah pengulangan bunyi vokal yang sama dalam satu baris.

Unsur bunyi berbentuk anafora yaitu pengulangan kata yang sama di awal baris berikutnya juga ditemukan dalam bentuk puisi di atas. Anafora tersebut terdapat pada kata hujan yang tertera pada baris ke-1, 3, 4, 5, 7, dan 8. Juga pengulangan kata di pada baris ke-2 dan ke-6.

Pada bentuk puisi di atas ditemukan juga epizeuksis yang terdapat hampir dalam setiap baris puisi. Epizeuksis adalah pengulangan kata yang dipentingkan secara langsung. Terlihat dalam baris ke-1 pada kata hujan dan hujan yaitu pengulangan kata /hujan/. Pada baris ke-3 kata hujan dan hujan kemudian henti dan henti yaitu pengulangan kata/hujan/ dan kata /henti/. Pada baris ke-4 kata hujan dan hujan, pengulangan kata /hujan/. Pada baris ke-5, 7, dan 8 juga pengulangan kata /hujan/.

Unsur bunyi berbentuk mesodiplosis yaitu pengulangan kata pertama di tengah baris juga ditemukan dalam puisi di atas. Mesodiplosis terdapat pada baris ke-2 yaitu ' $d i$ jalanan $d i$ halaman semua basah', pengulangan kata /di/, serta baris ke-6 yaitu ' $d i$ sana dan $d i$ sini air tergenang', juga pengulangan kata /di/.

Untuk unsur bunyi berbentuk epanalepsis dapat dilihat pada contoh kutipan puisi "Pelangi-Pelangi" berikut ini:

\section{Pelangi-Pelangi}

(simbol analisis)

Pelangi, pelangi

Pelangi, pelangi

(subtema 1, Pengalamanku di Rumah, pembelajaran ke- 1, hal: 12)

Epanalepsis adalah kata pertama yang diulang kembali pada kata terakhir. Epanalepsis dalam puisi tersebut terdapat pada kata-kata /pelangi/ dan /pelangi/. Sementara itu, unsur bunyi berbentuk onomatope dapat dilihat pada kutipan puisi "Tik tik tik Bunyi Hujan" berikut ini:

\section{Tik Tik Tik Bunyi Hujan (simbol analisis)}

1Tik tik tik bunyi hujan

(10)

2di atas genting 
(subtema 1, Pengalamanku di Rumah, pembelajaran ke-6, hal: 59)

Berdasarkan bentuk puisi tesebut ditemukan adanya onomatope yaitu peniruan bunyi. Hal tersebut ditemukan pada bari ke-1 dalam kata tik tik tik bunyi hujan.

Bentuk puisi di dalam buku tematik siswa SD kurikulum 2013 ini juga mengandung muatan diksi yang berasal dari bahasa asing. Puisi yang mengandung muatan diksi dalam bahasa asing ini hanya ada satu puisi yaitu puisi "Ketupat Lebaran" sebagaimana terlihat dalam kutipan berikut ini:

\section{Ketupat Lebaran (simbol analisis)}

$\cdots$ sepulang dari shalat

Disantap

Idul Fitri

Senangnya, subhanallah

asing

sungguh nikmat ....

Tersedia di meja sepulang dari asing

shalat

Memang sedap enak dan gurih

Cobalah ketupat, Alhamdulillah sungguh nikmat (2) asing

(subtema 2, pengalamanku di sekolah, pembelajaran ke-4, hal: 96)

Berdasarkan bentuk puisi di atas terlihat adanya diksi dalam bahasa asing yaitu bahasa Arab berupa kata shalat, idul fitri, subhanallah, dan Alhamdulillah.

Berikut ini adalah analisis tentang penggunan bentuk imaji. Penggunaan unsur imaji di dalam bentuk puisi pada buku tematik siswa SD kurikulum 2013 cukup beragam. sebagaimana terlihat melalui kutipan-kutipan puisi berikut ini:

\section{Taman bungaku (simbol analisis)}

Bila kupandang

Tamanku cantik

Oh angin dari segala rindu

Sebarlah harum bungaku

(subtema 1, pengalamanku di rumah, pembelajaran ke-4, hal: 40)

Imaji (citraan) dalam puisi di atas adalah berbentuk imaji penglihatan dan penciuman. Imaji penglihatan terdapat pada kata kupandang dan cantik. Sedangkan imaji penciuman terletak pada kata harum. Imaji penglihatan merangsang indera mata. Adapun imaji penciuman merangsang indera hidung.

Berikut adalah kutipan puisi yang mengandung imaji/citraan perabaan dan pendengaran.

\section{Cemara}

(simbol analisis)

Daunnya halus langsing

$/ \mathrm{d} /$

Menyentuh daun cemara

/d/

Terdengar desir di telingaku

[b]

Sebuah lagu merdu

(subtema 3, pengalamanku di tempat bermain, pembelajaran ke-3, hal: 141)

Citraan atau imaji yang terdapat dalam kutipan bentuk puisi di atas adalah berbentuk citraan perabaan dan pendengaran. Citraan perabaan terdapat dalam kata halus dan kata menyentuh. Adapun citraan atau imaji pendengaran terdapat pada kata terdengar, desir, dan telingaku serta pada kata lagu dan $m e r d u$. Pada kutipan puisi berikut ini terlihat adanya imaji/citraan pengecapan. 


\section{Ketupat Lebaran \\ (simbol analisis)}

Disantap sepulang dari shalat

<e>

Idul Fitri

....

Senangnya, subhanallah

<e>

sungguh nikmat

....

Ketupat lebaran dengan

<e>

sambal goreng hati

Memang sedap enak dan gurih <e>

Cobalah ketupat, Alhamdulillah sungguh nikmat <e>

(subtema 2, pengalamanku di sekolah, pembelajaran ke-4, hal: 9)

Berdasarkan kutipan puisi di atas terlihat adanya penggunaan imaji/citraan yaitu berbentuk citraan pengecapan. Hal tersebut terlihat dari penggunan kata disantap, nikmat, sambal, sedap, enak, dan gurih.

Di dalam buku tematik siswa SD kurikulum 2013 ini terdapat juga bentuk puisi yang mengandung muatan majas. Majas tersebut ada yang berbentuk majas personifikasi, hiperbola, simile, dan metafora. Untuk lebih detilnya dapat dilihat pada contoh kutipan puisi berikut ini:

\section{Cemara}

(simbol analisis)

Bergerakgerak kian kemari

personifikasi

Seperti tangan penari

personifikasi, simile

Menyentuh daun cemara

personifikasi

Terdengar desir di telingaku
Sebuah lagu merdu

metafora

(subtema 3, pengalamanku di tempat bermain, pembelajaran ke-3, hal: 141)

Majas yang ditemukan dalam bentuk puisi tersebut adalah berbentuk majas personifikasi yaitu dalam ungkapan bergerakgerak kian kemari seperti tangan penari. Ungkapan tersebut mengandung makna bahwa benda dapat berbuat seperti manusia yaitu pohon cemara yang bergerak-gerak seperti tangan penari. Selain itu, terdapat juga majas perbandingan atau simile dalam kata seperti tangan penari. Selain simile ada juga majas perbandingan lain yang ditemukan yaitu majas metafora. Majas tersebut terdapat dalam pernyataan berikut yaitu terdengar desir di telingaku, sebuah lagu merdu. Pernyataan itu mengandung arti desir yang terdengar bagaikan lagu merdu. Karena tidak menggunakan kata pembanding maka majas tersebut dinamakan metafora.

\section{Burung Kutilang (simbol analisis)}

Bersiul-siul sepanjang hari personifikasi

....

Mengangguk-angguk sambil berseru personifikasi

Digeleng-gelengkan kepalanya personifikasi

Menentang langit biru

hiperbola

Tandanya suka ia berseru personifikasi

(subtema 1, pengalamanku di rumah, pembelajaran ke-5, hal: 43)

Majas yang terdapat dalam puisi di atas adalah berbentuk majas personifikasi dan hiperbola. Majas personifikasi terletak pada kata bersiul-siul, berseru, mengangguk- 
angguk, dan digeleng-gelengkan. Majas personifikasi adalah mempersamakan benda dengan manusia, seolah-olah benda bisa berbuat seperti manusia (Pradopo: 77). Adapun majas hiperbola adalah pengungkapan sesuatu secara berlebihan yang seakan tidak bisa terjadi. Majas hiperbola dalam bentuk puisi di atas terdapat pada bentuk menentang langit biru.

Berdasarkan hasil analisis, bentuk puisi di dalam buku tematik siswa SD kurikulum 2013 ada juga yang menggunakan penyimpangan bahasa. Penyimpangan bahasa tersebut berbentuk penyimpangan morfologis, sintaksis, dan grafologis. Sebagaimana terdapat dalam kutipan puisi berikut ini:

\section{Paman Datang (simbol analisis)}

Dan sayur mayur segala rupa

sintak, grafo

...

Hatiku girang tidak terperi

morfo

(subtema 3, pengalamanku di tempat bermain, pembelajaran ke- 5, hal: 152)

Di dalam bentuk puisi tersebut ditemukan juga adanya penyimpangan bahasa yaitu dari segi sintaksis, morfologi, dan grafologi. Penyimpangan bahasa dari segi sintaksis ditemukan pada bentuk kata dan sayur mayur segala rupa. Berdasarkan bentuk tersebut terlihat penggunaan kata hubung dan yang kurang tepat diletakkan di awal kalimat. Adapun penyimpangan bahasa dari segi morfologis terdapat pada kata terperi. Kata terperi bukanlah bentuk kata yang lazim dan baku dalam bahasa Indonesia. Sedangkan penyimpangan bahasa dari segi grafologis adalah dalam hal penggunaan tanda baca. Hal ini terlihat pada kata sayur mayur di mana pada bentuk tersebut tidak ada tanda hubung $(-)$.
Berikut ini akan dibahas bagaimana berbagai unsur yang ditemukan dalam bentuk puisi anak pada buku tematik siswa SD kurikulum 2013 ini jika dikaitkan dengan karakteristik sastra anak yang dapat membentuk kepribadian anak. Sebagaimana yang dikatakan Supriyadi (2006: 12) dan Sarumpaet (dalam Supriyadi, 2006:21) bahwa sastra anak memiliki beberapa karakteristik yaitu dari segi kebahasaan, kesastraan, pantangan, penyajian, dan fungsi terapan.

Dari segi penggunaan bahasa, pada bentuk puisi anak yang terdapat dalam buku tematik siswa SD K-13 ini sangat terlihat pada penggunaan diksi atau pilihan kata. Di dalam bentuk puisi anak pada buku tematik ini hampir semuanya menggunakan kosakata konkret. Hal tersebut terlihat jelas dari judul puisi yang digunakan. Semua judul bentuk puisi tersebut berbentuk kosakata konkret. Judul-judul puisi tersebut adalah sebagai berikut: Pelangi-pelangi, Lihat Kebunku, Taman Bungaku, Burung Kutilang, Burung Berkicau, Tik tik tik Bunyi Hujan, Hujan, Ketupat Lebaran, Layang-layang, Kunangkunang, Cemara, Kupu-kupu, Paman Datang, Nyiur Hijau, Pemandangan, Air Terjun, dan Desaku. Berdasarkan dari judul-judul puisi tersebut terlihat sekali bahwa pemilihan kosakata konkret sangat mendominasi di dalam puisi anak.anak. Banyaknya penempatan kosakata konkret dalam bentukbentuk puisi anak ini sangat tepat dan sejalan dengan faktor perkembangan usia anak. Menurut Piaget, seorang ahli psikolog Swiss (1896-1980) yang menyatakan bahwa anak usia 7-11 tahun adalah berada pada fase operasional konkret. Pada usia ini mereka mulai berpikir logis namun membutuhkan contoh-contoh yang konkret. Maka dengan demikian, melalui kosakata konkret yang terdapat dalam bentuk-bentuk puisi anak tersebut akan sangat membantu anak dalam memahami dunia sekitarnya.

Penggunaan kosakata konkret ini sejalan juga dengan pendapat Supriyadi (2006: 4) tentang hakekat sastra anak adalah 
karya sastra imajinatif yang ditulis oleh anakanak maupun orang dewasa yang ditujukan bagi anak-anak dengan menggunakan bahasa yang mengandung pengalaman, pikiran, dan perasaan anak-anak. Sastra anak adalah karya sastra yang berisi tentang masa anak-anak. Menceritakan tentang kehidupan anak-anak. Sebagaimana dikatakan oleh Piaget bahwa pada usia 7-11 tahun anak-anak berada pada masa konkret. Maka, sangatlah sesuai jika penggunaan kosakata konkret banyak ditemukan dalam sastra anak yang dalam hal ini puisi anak. Sesuai dengan masa yang mereka alami.

Bentuk-bentuk puisi anak yang terdapat dalam buku tematik siswa SD K-13 ini menggunakan beberapa unsur sastra seperti pemanfaatan unsur bunyi, majas, dan imaji (citraan). Penggunaan unsur bunyi ditemukan adanya bentuk repetisi (pengulangan) bunyi yang meliputi rima, aliterasi, asonansi, anafora, epizeuksis, epanalepsis, mesodiplosis, onomatope. Sedangkan dalam penggunaan majas ditemukan adanya majas personifikasi, hiperbola, metafora, simile. Adapun penggunaan imaji (citraan) adalah berupa imaji penglihatan, penciuman, pendengaran, dan perabaan.

Hampir semua puisi dalam buku tematik siswa SD K-13 ini memiliki unsur bunyi berupa rima, alitersi, dan asonansi. Sementara unsur-unsur yang lain hanya dimiliki oleh satu-satu puisi saja. Unsur rima atau persajakan bunyi akhir ini ada yang berbentuk simetris. . Hal ini sesuai dengan yang dikatakan Supriyadi bahwa karakteristik puisi anak (2006: 18) terlihat dari persajakan (rima) dan irama biasanya berbentuk simetris seperti pantun, yaitu bersajak a, b, a, b atau seperti syair bersajak a, a, a, a.

Berdasarkan bentuk puisi anak dalam buku tematik ini ditemukan juga adanya beberapa pemakaian majas. Secara keseluruhan majas yang digunakan juga tidak terlalu banyak, hanya ada beberapa penggunaan majas saja seperti personifikasi, metafora, dan simile. Hal ini cukup sejalan dengan pendapat Supriyadi (2006: 12) yang menyatakan bahwa puisi anak biasanya tidak banyak mengandung majas atau gaya bahasa. Salah satu majas yang banyak digunakan adalah majas personifikasi.

Bentuk puisi anak dalam buku tematik siswa ini juga memiliki penggunaan citraan atau imaji. Hampir semua bentuk puisi mempunyai unsur citraan atau imaji. Banyaknya pemanfaatan unsur imaji atau citraan dalam puisi anak sangatlah tepat mengingat usia anak-anak berada dalam masa operasional konkret. Pada masa ini anak-anak relatif cukup dominan mempergunakan panca indera dalam rangka membangun pemahaman yang didapatkannya. Anak akan lebih memahami sekitarnya jika hal tersebut bisa dilihat, didengar, dicium, dan diraba. Di dalam masa konkret ini diartikan juga sebagai proses belajar yang beranjak dari hal-hal konkret yang dapat dilacak oleh pancaindera secara nyata sehingga mudah untuk dipertanggungjawabkan (Sumantri, 161).

Karya sastra anak memiliki sejumlah pantangan. Sebagaimana yang dikatakan Sarumpaet (dalam Supriyadi, 2006: 22) bahwa sastra anak harus menghindari tema yang bersifat dendam, menimbulkan kebencian, seks, prasangka buruk, kecurangan, serta persoalan tentang kematian.

Di dalam bentuk-bentuk puisi yang terdapat dalam buku tematik siswa SD ini tidak ditemukan adanya tema yang mengangkat unsur pantangan tersebut. Hal ini dapat dilihat melalui judul-judul puisi yang tertera. Semua judul puisi tersebut tidak memiliki indikasi pantangan.

Dari segi penyajian, karakteristik sastra anak adalah disajikan dengan cara yang langsung. Hal ini dikaitkan dengan segi kebahasaan (Supriyadi, 2006: 21). Di dalam bentuk-bentuk puisi dalam buku tematik siswa SD ini terlihat dari segi penggunaan bahasa banyak menggunakan kosakata konkret. Ini menunjukkan bahwa penyajiannya bersifat langsung. 
Karakterisitk sastra anak dari segi terapan adalah dilihat dalam hal manfaat sastra bagi anak-anak. Sastra anak mengandung unsur yang dapat bermanfaat untuk diterapkan dalam kehidupan anak, baik dalam hal yang bersifat pengetahuan secara umum maupun keterampilan secara khusus ataupun dalam bentuk pertumbuhan anak (Supriyadi, 2006: 23). Sementara itu, Huck et al dalam (Supriyadi, 2006: 4) menyatakan bahwa nilai sastra anak dapat dikelompokkan dalam dua hal yaitu dari segi kepribadian (personal value) dan dari segi pendidikan (educational value).

Berdasarkan hasil temuan analisis, bentuk-bentuk puisi anak yang terdapat dalam buku tematik siswa SD ini mengandung beberapa fungsi terapan, seperti dari segi pengetahuan atau pendidikan yaitu berisi muatan pengetahuan yang dapat menambah informasi dan wawasan siswa. Dari segi kepribadian dapat menumbuhkan pribadi yang santun, relijius, ramah, penyayang, ceria, hangat, berjiwa seni, suka berbagi, dan cinta tanah air.

\section{SIMPULAN}

Berdasarkan hasil penelitian dan analisis data terhadap bentuk-bentuk puisi yang terdapat dalam buku tematik siswa SD ini ditemukan adanya beberapa penggunaan sarana stilistika yaitu berupa pemanfaatan unsur bunyi yang terdiri atas rima, aliterasi, asonansi, epizeuksis, anafora, epanalepsis, mesodiplosis, dan onomatope. Sementara itu, penggunaan diksi dalam bentuk puisi pada buku tematik ini adalah berupa diksi dari bahasa asing yaitu bahasa Arab. Adapun penggunaan imaji atau citraan adalah berbentuk citraan penglihatan, pendengaran, penciuman, dan pengecapan. Sedangkan pemanfaatan majas adalah berupa majas personifikasi, hiperbola, metafora, dan simile. Selanjutnya, untuk penggunaan sarana retorika adalah berbentuk retoris. Kemudian dalam penyimpangan bahasa ditemukan adanya penyimpangan morfologis, sintaksis, dan grafologis.

Ditinjau dari karakteristik puisi anak, puisi-puisi yang terdapat dalam buku tematik siswa SD ini sudah memenuhi kriteria sebagai puisi anak. Bentuk-bentuk puisi tersebut sudah mempunyai manfaat sastra bagi anak yaitu dari segi pengetahuan dan kepribadian.. Dari segi pengetahuan atau pendidikan dapat menambah informasi dan wawasan siswa. Dari segi kepribadian dapat membantu menumbuhkan dan membentuk pribadi yang santun, relijius, ramah, penyayang, ceria, hangat, berjiwa seni, suka berbagi, dan cinta tanah air.

\section{DAFTAR PUSTAKA}

Arifin, S. (1991). Kamus Sastra Indonesia. Padang: Angkasa Raya.

Atmazaki. (1993). Analisis Sajak: Teori, Metodologi, dan Aplikasi. Bandung: Angkasa.

Budianta, M. (2008). Membaca Sastra, Pengantar Memahami Sastra untuk Perguruan Tinggi. Magelang: Indonesia Tera.

Endraswara, S. (2011). Metodologi Penelitian Sastra, Epistemologi, Model, Teori, dan Aplikasi. Yogyakarta: FBS Universitas Yogyakarta.

Gani, R. (1988). Pengajaran Sastra Indonesia: Respon Analisis. Jakarta: P2LPTK Direktorat Jenderal Pendidikan Tinggi Depdikbud.

Keraf, Gorys. (2007). Diksi dan Gaya Bahasa. Jakarta: Gramedia.

Kosasih, E. (2012). Dasar-Dasar Keterampilan Bersastra. Bandung: Yrama Widya.

Moleong, Lexy ?. (1990). Metodologi Penelitian Kualitatif. Bandung: PT Remaja Rosdakarya

Natawidjaya, P. \& Suparman. (1986). Apresiasi Stilistika. Jakarta: Intermasa.

Nurgiyantoro, B. (2019). Sastra Anak: Pengantar Pemahaman Dunia Anak. 


\section{PRIMARY: JURNAL PENDIDIKAN GURU SEKOLAH DASAR \\ VOLUME 10 NOMOR 4 AGUSTUS 2021 \\ ISSN : 2303-1514 | E-ISSN : 2598-5949 \\ DOI : http://dx.doi.org/10.33578/jpfkip.v10i4.8462 \\ https://primary.ejournal.unri.ac.id/index.php/JPFKIP}

Yogyakarta: Gadjah Mada University Press.

Pradopo, R. D. (1995). Pengkajian Puisi. Yogyakarta: Gadjah Mada University Press.

Ratna, N. K. (2017). Stilistika, Kajian Puitika Bahasa, Sastra, dan Budaya. Yogyakarta: Pustaka Pelajar.

Ratna, N. K. (2015). Teori, Metode, dan Teknik Penelitian Sastra dari Strukturalisme hingga Poststrukturalisme Perspektif Wacana Naratif. Yogyakarta: Pustaka Pelajar..

Semi, M. Atar. (1988). Anatomi Sastra. Padang: Angkasa Raya.

Semi. (1990). Stilistika Sastra. Padang: Angkasa Raya.

Sudjiman, P. (1993). Bunga Rampai Stilistika. Jakarta: Pustaka Utama.

Sumarjo, J. (1986). Apresiasi Kesusastraan. Jakarta: Gramedia

Sumantri, M. \& Syarif. (2016). Strategi Pembelajaran: Teori dan Praktik di
Tingkat Pendidikan Dasar. Jakarta: Rajawali Pers.

Supriyadi. (2006). Pembelajaran Sastra yang Apresiatif dan Integratif di Sekolah Dasar. Jakarta: Dirjen Dikti Direktorat Ketenagaan.

Taufina. (2017). Pengalamanku, Tematik Terpadu Kurikulum 2013, Tema 5, Untuk Siswa SD/MI Kelas II. Edisi Revisi 2017. Jakarta: Kementerian Pendidikan dan Kebudayaan.

Tarigan, H. G. (1993). Prinsip-prinsip Dasar Sastra. Bandung: Angkasa.

Waluyo, H. (1987). Teori dan Apresiasi Puisi. Jakarta: Erlangga.

Wellek, R. (1990). Teori Kesusastraan. Jakarta: Gramedia. 